\title{
Participation of students in University Governance: A case of Mwenge Catholic University, Tanzania
}

\author{
Rev. Eugene Lyamtane (PhD) and Evans Ogoti (PhD) \\ Mwenge Catholic University \\ Faculty Of Education \\ P.O Box 1226 Moshi -Tanzania
}

\begin{abstract}
This study focused on participation of students in University governance. Specifically it was anchored on shared governance principle to interrogate the levels of student's participation, with the view to understanding the extent to which students, as major stakeholders, have been mainstreamed in the democratization of governance in Mwenge Catholic University. Utilizing the convergent parallel design.to collect both qualitative and quantitative data, merge the data and use the results to understand the research problem. Both probability and non-probability sampling techniques were used. Data was collected from 84 students, three deans of faculties, one director and two University administrators. The study concluded that Mwenge Catholic University recognize, both in principle and practice, the importance of students' participation in governance processes and that the nature and level of participation of students in the governance processes in the University has been articulated and students attach high importance in their inclusion in various governance structures. The study recommends that a paradigm shift should occur in the University, concerning the handling of students' involvement and participation in the governance process and the university should formulate specific strategies for the nurturing and entrenching of a democratic and participative culture among students as well as among all cadre of management staff.
\end{abstract}

Key words; governance structures, participation, decision making process and levels of satisfaction

\section{Introduction}

University education is expected to serve the primary function of nation-building and development (Kauffeldt 2009; Mosha 1986; World Bank 2009). Universities are expected to make a sustained contribution to development by equipping human resource with relevant knowledge, skills and value systems through their diversified academic programmes and through the generation and dissemination of relevant knowledge (Bailey, Cloete and Pillay 2013). University education should enable individuals to develop their capabilities to the highest potential; serve the needs of an adaptive, sustainable and knowledgebased economy and play a major role in the shaping of a democratic, civilized and inclusive society (Okioga, Onsongo and Nyaboga 2012). The sector should produce graduates that are able to compete in a global economy with those that are products of the well-established Western higher education systems (Kauffeldt 2009; Santiago et al. 2008; World Bank 2002, 2009). Access to university education is an important tool for sustainable socio-economic development and for rapid development and improvements in human capital (Ndegwa 2008). Education in general, and university education in particular, is viewed as the primary means of social mobility but also as a basis for national cohesion and socio-economic development (Kinuthia 2009; Nyangau 2014). The government recognizes that education and training of all Tanzanians is a fundamental development agenda. In particular, it sees the country's future as a prosperous and internationally competitive nation to be dependent on the university education system. The sector has the responsibility of creating a knowledge-based society that upholds justice, democracy, accountability and encourages issue-based and results-oriented political engagements. 
Despite the above recognition of higher education as a key driver of socioeconomic development in Africa, initially, governments did little to promote the development role of universities, partly because many of them had not developed a coherent development model and also because many had become increasingly embroiled in internal power struggles, and the external politics of the Cold War and funding agencies such as the World Bank (Cloete., Bailey., Pillay,. Bunting,and Maassen, 2011). It was not until the 1990s and early 2000s that some influential voices started calling for the revitalization of the African university and for linking higher education to development (Sawyerr 2004). The World Bank (2000), for example, inspired by Castells' (1991) path-breaking paper, 'The University System: Engine of development in the new world economy', started recognizing the role of higher education in the knowledge economy and in development in the developing world. This was subsequently strengthened by the findings of other empirical studies (e.g., Bloom, Canning, and Chan, 2006; Kamara and Nyende 2007; World Bank 2009) that associated higher education with gross domestic product in Africa. The resurgence of support for the university as an avenue for development in Africa was best captured by Kofi Annan, the then Secretary General of the United Nations, when he stated that:

The university must become a primary tool for Africa's development in the new century. Universities can help develop African expertise; they can enhance the analysis of African problems; strengthen domestic institutions; serve as a model environment for the practice of good governance, conflict resolution and respect for human rights, and enable African academics to play an active part in the global community of scholars (quoted in Bloom et al. 2006: 2).

The university sub-sector is also expected to equip citizens with understanding and knowledge that enables them to make informed choices about their lives and to confront the challenges facing the Tanzanian society. Among the middle class, university education is seen as guaranteeing lifelong secure careers. That is, it enables individuals to cope with the changing nature of the job market characterized by frequent changes of jobs; university education enhances one's chances for advancement in current employment and creates prospects for future careers (Gudo, Olel and Oanda 2011).

Across the African continent, the growing awareness of the critical role of university education in socioeconomic development, coupled with the recognition of the twenty-first century as 'a knowledge era' has pushed governments in virtually all countries to endeavour to improve access to relevant and quality university education by building new universities while, at the same time, increasing enrolment at existing ones (Okioga, Onsongo and Nyaboga 2012; Reisberg 2010). This has resulted in massive expansion both in the number of public and private university institutions as well as in enrolment, with most of the growth occurring since 2000. Building on tiny and initially elitist universities, many African countries have witnessed rapid expansion in higher education since independence. In Tanzania, for example, the government has invested heavily in all sectors of education with the view to widening access to education at all levels. Such investments resulted in the country experiencing exponential growth in primary, secondary and tertiary and university education. The growth has been accompanied by the revision of curricula and the upgrading of educational standards or quality. The term 'massification of higher education' has often been used to refer to the dramatic growth in public and private sector universities coupled with astronomical increments in the number of students enrolled (Jowi 2003; Kaburu and Embeywa 2014). By massification of university education we mean growth of enrolment beyond the capacities of universities (Jowi 2003). The meaning of the term though transcends the growth in numbers of institutions and students to include the absence of corresponding increases in budgetary allocation and investments in facilities and staff (Kaburu and Embeywa 2014).

In many countries in Eastern Africa, the massification of university education has occasioned the establishment of public and private universities and colleges that lack the infrastructural facilities (such as lecture theatres, laboratories, libraries, and faculty offices) essential for quality learning and training (Ngome 2003; Musisi and Muwanga 2003). In addition, institutions of higher learning in Africa must contend with inadequate and poorly trained (unskilled) faculty coupled with the lack of qualified professors with graduate degrees or research experience (Reisberg 2010). This has mainly been occasioned by the continuing brain drain or the departure of the skilled and experienced scholars and scientists (Seth 2000; Kelly 2001; Effah 2003; Ngome 2003; Wondimu 2003) to Europe, North America and Southern Africa in search of better 
remuneration. In some countries, the situation is compounded by long-standing economic and social crises and rampant corruption which siphons resources allocated for socioeconomic development (Seth 2000; Kelly 2001; Effah 2003; Ngome 2003; Wondimu 2003; Damtew and Altbach 2004; Saint 2004).

An often forgotten challenge facing many African universities is the crisis of governance. Governance has been demonstrated to play a pivotal role in the success of institutions of higher learning and is a crucial factor in sustaining and improving quality and performance (Gibbs, Knapper and Picinnin 2009; Osseo,Asare, Longbottom and Murphy 2005; Martin, Trigwell, Prosser and Ramsden 2003). To deal with the governance crisis affecting them and to fulfil their roles, universities must embrace good governance. The existence of good governance in universities is a function of a combination of factors. First, it requires visionary, creative (innovative) and inclusive leadership equipped with good communication skills capable of driving change (Brookes 2006; Craig 2005; Lownsborough and O'Leary 2005; NCSL 2008a). Second, it demands adherence to the key principles of good governance; that is, academic freedom, shared governance, clear rights and responsibilities meritocratic selection, financial stability and accountability (Kauffeldt 2009; Obondo 2000; OECD 2003; Task on University Education and Society 2000). Third, universities can achieve good governance harnessing the following tools and practices effectively: faculty councils (or senates), governing councils (or board of trustees), institutional charters and handbooks, visiting committees and accreditation, budget practices and financial management, data driven decision making, style of identifying leaders (appointing or electing), faculty appointment and promotion decisions and security of employment (Task on University Education and Society 2000).

According to the University ACT, 2005. Every university in United Republic of Tanzania shall by notice publish in the Gazette or prospectus of the university provided under its charter for a common students' organization. The membership of and affairs of the students organization shall be governed by its constitution. Constitution of the students' organization shall be subject to approval by the Council and this has to be done with fairness and transparency. The ACT however, does not specify how the student organization leaders participate in University governance structures.

This study focused on participation of students in University governance. In particular, it keys on the shared governance principle of good governance to interrogate the levels of student's participation, with the view to understanding the extent to which students, as major stakeholders, have been mainstreamed in the democratization of governance in Mwenge Catholic University. The study is premised on the reality that collaborative governance is essential if universities are to attain their visions, missions and goals. Also, students are the majority of the institutions' community and finance the larger part of the institutions' budgets. As such, they have a right to representation in decision making and policy formulation. For students to effectively participate in the governance of their institution, their leadership should not just be involved in some matters. But rather it should be adequately involved in all major decision and policy issues affecting the university. The university should also provide the student leadership with the resources they require to be adequately involved in its governance structures.

\section{Statement of the Problem}

The Vision of Mwenge Catholic University is to be a leading university that sets a national, regional and international example in education and training, research and consultancy as well as community service. Its mission is to produce professionally competent, innovative and committed graduates who are grounded on professional excellence and moral integrity for the provision of quality service to Tanzania and global community. From vision and mission statements it is very clear that the University's goal is to have a sustainable, quality and relevant university education for national development. Like elsewhere in the world, for Mwenge Catholic University to meet its goals, it must meet high quality standards and its contents must remain relevant to the needs of the economy and society. One of the factors that infringes on the university capacity to deliver a quality and relevant education is the way the university is governed. The existing evidence suggests that consistent with the practice in other universities, Mwenge Catholic University suffers from the violation of the core principles of good governance, including that of shared governance. This calls for renewed efforts to democratize governance in universities by ensuring that decision making and policy formulation are truly participatory. However, doing so can be an uphill task without the support and active participation of students. Student leadership and student voice must be integrated into the governance of institutions of higher learning not just in principle (or as an act of tokenism) but also in practice. This 
demands the input of the total student body through the officials of student government and other organized students' groups (e.g. associations and clubs). Given that students are the majority members of the university community, administrators at all levels of management of universities must be seen to forge a strong collaborative partnership with student leadership. Such partnership must exist from the department as the lowest administrative unit, to the office of the vice-chancellor, who is the chief executive of the institution. For the partnership to be functional it should be truly consultative and characterized by shared decision making by both parties, with students having co-decision rights.

As such, there is a need for studies that not only assess the extent to which student leadership has been mainstreamed into the governance of Universities but also spotlight the quality of student leadership in our universities, its capacity to serve effectively as well as identify the factors that stand in the way of strong and effective student leadership. It is in this spirit that this study has been designed. In addition, although the existing literature shows that the subject of student leadership in general in universities has been the focus of previous studies (Klemenčič 2014; Luescher-Mamashela et al. 2011; Obondo 2000; Mwiria 1992), not much investigation has been conducted focusing on the mainstreaming of student leadership into the governance of universities and how the quality of student leadership infringes on that process in a comprehensive fashion. Furthermore, no studies that we are aware of have been conducted in Mwenge Catholic University systematically focusing on the contexts of student Participation in university governance. This study was designed with the broad purpose to address the above gaps.

\section{Research questions}

1. To what extent does official university policy documents as well as governance structures and practices in MWECAU accommodate student participation in governance

2. What is the level of importance students in MWECAU attach to their participation in governance and decision making processes?

3. What is the extent, adequacy of and level of satisfaction with student participation in governance and decision making processes in MWECAU

4. What challenges face effective student participation in University governance, from the perspective of different stakeholders

\section{Theoretical Framework}

The study was guided by the democratic theory to explain students' participation in university governance, zeroing in on how key decisions are made and who makes them. According to Fung (2007:444), democracy is about non-tyranny or the principle that 'no individual or group should decide collective issues regardless of others' interests and preferences'. Underpinning democracy are values such as popular representation; universal suffrage; freedom of speech; assembly; organization and the press (Thierborn, 1977:4); accountability; self-government; reasoned rule; common good, and; self-actualization (Fung 2007), among others. Relative to other forms of governance, democracy is preferable because it renders the leadership accountable to its stakeholders.

Democratic theory is concerned with processes by which ordinary citizens exercise a relatively high degree of control over leaders (Dahl 2006). It examines structures and processes of decision-making from the student perspective to assess whether they are participatory. Democratic theories identify 'democracy' with political equality, popular sovereignty, and rule by majorities. In democratic environments people determine public policy, laws and actions of their state together. Building on Aristotle's political ideas, participatory democracy or decision-making was born out of the need to explain how ordinary citizens should be involved more in deciding their collective affairs. Participatory democracy has the advantage of ensuring equity, selfdetermination, sense of community, acceptability and, relevance of the decisions made by the key stakeholders of the organization. Participation grows transparency by opening up policy formulation and implementation processes to all stakeholders through direct or representative involvement. Through the participatory processes, practical 'people-based' knowledge is shared, debated, combined with technical knowledge and built into the policy process. Participation also increases the bargaining power of stakeholders (Wainwright 2005). This occurs mainly because participation tends to redistribute power among stakeholders. Participatory democracy enables stakeholders to monitor the work of the executive and other top managers/ administrators. Popular participation lets people, as well as officials, decide the detail on how broad policy commitments are carried out (Wainwright 2005), meaning that how public policy is 
administered is not value neutral. The legitimacy of participatory democracy lies in the high degree of activity of what is likely to be a minority through institutions that are transparent, open to all and, based on mutually agreed rules.

According to Wainwright (2005), participatory democracy provides a real alternative, or complement, to elected power: a distinct and organized public sphere in which the demands of the people can be articulated, developed and negotiated between each other, and finally negotiated with the local or other relevant institutions. However, for participatory democracy to be feasible, attain legitimacy, and reinvigorate democratic practices as a whole, certain conditions are required. First, the structures for participation should be open at their foundations to everyone affected by such decisions - even if only a minority participate. As Wainwright (2005) underlined, 'openness is not just a formality; it needs to be worked at'. While not everyone may directly participate, all stakeholders need to be in contact with someone who participates. In the case of this study, this means that while not every student must be involved in decision making directly, all students need to be connected to someone who is involved; that is student representatives or leadership. Second, participatory democracy requires mutually agreed and openly negotiated rules to regulate the interaction among and behaviour of stakeholders. The legitimacy of participatory democracy is also pegged on the autonomy of the participatory process from the State (Wainwright 2005), in our case the top managers/ administrators of the university. This is important because participatory institutions have the goal to eventually share decision-making power with government, to exercise some control over the work of State institutions and, to monitor the implementation of government's decisions. Such relationships, though, are contingent on equality, meaning that participatory institutions need to have their own life and dynamism, and to know that the top governance body respects this. A fourth condition for the legitimation of participatory democracy is that there must be genuine sharing of knowledge (Wainwright 2005). In addition, participation must be anchored on real resources that have significance to the lives of the stakeholders. In other words, the consultation must be a process that gets result and not just another consultation exercise leading nowhere (Wainwright 2005). The final condition enhancing the feasibility and legitimacy of the participatory process is the existence of a governance body that believes in it. Referring specifically to the university education environment, the argument here is that for participatory democracy to thrive the top administrator of the university must believe and have faith in this form of governance. The main contention upon which the key theories of participatory democracy are based is whether citizens should make decisions for themselves through direct democracy or let others make decisions on their behalf through representative (liberal) democracy (Schmidt 2002). Direct democracy is characterized by direct participation of all the stakeholders in the decision-making processes including policy-making and determination of the actions to be taken by the governing body. While this is a practice that gives an opportunity to each group member to exercise control of the direction their lives will take, its applicability has been curtailed by the large membership of most groups, rendering group decision making inefficient and ineffective. Another criticism levelled against this mode of democracy is that the masses lack the time, wisdom and good judgment to make relevant decisions.

James Madison, the late eighteenth and early nineteenth century American political theorist and statesman, was among those who developed and presented arguments against direct democracy. The opponents of direct democracy argued that the masses should be represented by governing elite groups of people elected to represent their interests in what is known as representative or liberal democracy (Baker 1997). Liberal democracy is a form of government in which representative democracy operates under the principles of liberalism, i.e. protecting the rights of the individual, which are generally enshrined in law. Bollen (1993) defines liberal democracy as 'the extent to which a political system allows political liberties and democratic rule'. The existence of political liberties is reflected in the extent to which people enjoy freedom to voice their political opinions and to form and participate in political groups (Bollen 1993). Democratic rule, on the other hand, exists if the national government is accountable to the general population and individuals have the right to participate in government either directly or through representation (Bollen 1993). In a liberal democracy, among others, there are attempts to defend and increase civil liberties against the encroachment of governments, institutions and powerful forces in society; restrict or regulate government intervention in political, economic and moral matters affecting the citizenry; and, to increase the scope for religious, political and intellectual freedom of citizens (http://australianpolitics.com/democracy/keyterms/liberaldemocracy). Liberal democracy is hinged on the premise that governing power is not exercised 
directly by the whole body of stakeholders but by representatives elected by members through a voting system. Thus, legislative decision-makers should acquire political authority by means of a competitive but peaceful and legal struggle for the support of a majority of the electorate. Liberal democracy acknowledges the importance of civil society organizations (Wainwright 2005). This is based on the conventional acceptance that a strong civil society keeps elected representatives on their toes. This occurs through organized interest groups pressing their causes on government, sometimes through political parties, sometimes through independent lobbies. This form of democracy is a salient feature of the contemporary world; it has taken root in the Western democratic political systems, such as the United States, Britain, Germany, Japan, Australia, New Zealand, Canada etc., and is being tried in many other countries (Bollen 1993). We acknowledge that the benefits of both the direct and representative democratic theories can be maximized in organizational governance to enrich participation experiences of key stakeholders. However, for the purpose of this study the liberal (or representative) democracy theoretical framework was utilized to isolate the governance structures, activities and, processes that enabled university students to participate in decision-making either directly or through representation. The study advances the view that, in principle, public and private universities have embraced the democratization of decision-making, in which shared (or participatory) governance is a common feature. In this scheme of things, students, as major stakeholders in universities, are expected to play a major role in policy-formulation and decision-making in these institutions. However, rather than rely on direct democratic governance in which all students are involved in decision-making (or make decisions for themselves), universities have adopted the liberal democratic model in which students participate in policy-formulation and decision -making through elected (or in some cases appointed) representatives, who are expected to champion the interests of the total student community. Such representation occurs through structures such as student unions, clubs, committee membership and, voting for student leaders (Baker 1997)

\section{Research Design and Methodology}

The study adopted mixed research method approach where by convergent parallel design guided the study. The purpose of using convergent of Parallel mixed methods design was to simultaneously collect both qualitative and quantitative data, merge the data and use the results to understand a research problem. Mixed method approach not only allows the researchers to be more confident in the results of the study but also provides a clearer understanding of the phenomenon of the study (Jick 1979; Thurmond 2001; Johnson, Onwuegbuzie and Turner 2007). To illustrate, the researchers are able to use qualitative data as the critical counterpoint to quantitative data and by so doing, the quantitative analysis benefits from the perceptions emanating from the personal experiences and the firsthand observations of the qualitative approaches (Jick 1979). More specifically, by combining the quantitative and qualitative approaches, this study sought to not only bring out the major trends (patterns) and practices in student leadership but also to elicit specific voices from students and academic managers and policy-makers. Utilizing mixed methods is not without limitations. For instance, it makes replication exceedingly difficult (Jick 1979; Thurmond 2001).

Data for this study was collected from 84 students, three deans of faculties, one director and two University administrators. Making a total of 90 respondents. The selection of students was conducted through probability sampling procedure to select 36 class representatives and 48 students from undergraduate and postgraduate academic programees 14 students of MWECAUSO students leaders were selected through purposive sampling procedures as key informants. The deans, directors and university administrators were selected using purposive sampling technique. To supplement data collected from the primary respondents, interviews were conducted with key informants and focus group discussions (FGDs) were held with selected students leaders. The key informants were selected purposively and included two top management officials. Consistent with the selection of the study's primary respondents, students participating in the FGDs were also selected from the student governing body which comprised of 14 students. The study employed a combination of self-administered survey, key informant interview guide and focus group discussions (FGDs) to collect opinions from students and other stakeholders in the governance process.

The bulk of the data realized by the study was managed and processed utilizing SPSS computer Software. The analysis occurred in two stages. The first stage involved the processing of surveys administered to the primary respondents of the study utilizing the SPSS quantitative data analysis software. During this stage, descriptive statistics especially frequency distributions, percentages and, where applicable, means were 
computed and utilized to display data patterns; that is, to construct a descriptive profile of the study sample and to depict the patterns in the influence of policies and practices targeted by the study. The second stage in the data management and analysis process involved the transcribing of in-depth interviews and FGDs. These were transcribed and categorized by questions. Patterns from these sources of data constituted a basis for the cross-validation of results (patterns) obtained from the quantitative data. Interpretation was based on themes which emerged from the data and were supported by selected quotes.

\section{Discussion of Findings \\ Mainstreaming of participation in Governance and decision making in university Policy Documents, Governance Structures and Practices}

The first research question of this study was to determine the extent to which official university policy documents, governance structures and practices mainstream students' participation in governance and decision-making processes. This was captured through the analysis of university mission and vision statement and the Charter, questionnaires administered to 84 students, in-depth interviews with key informants (KIs) and focus group discussions (FGDs) with selected students. The survey results for the mainstreaming of students' involvement in participation in institutional strategic/ policy documents and practices are presented in Table 1

Table 1.Mainstreaming of students' involvement in participation in institutional strategic/ policy documents and practices

\begin{tabular}{|c|c|c|c|c|}
\hline \multirow[t]{2}{*}{ Statement } & \multicolumn{2}{|l|}{ A } & \multicolumn{2}{|l|}{$\mathrm{D}$} \\
\hline & $\mathrm{F}$ & $\%$ & $\mathrm{~F}$ & $\%$ \\
\hline $\begin{array}{l}\text { 1. My university has a published policy on student involvement in } \\
\text { governance }\end{array}$ & 62 & 73.8 & 22 & 26.2 \\
\hline $\begin{array}{l}\text { 2. The statutes governing my university makes reference to student } \\
\text { involvement in the governance process }\end{array}$ & 51 & 60.7 & 33 & 39.3 \\
\hline $\begin{array}{l}\text { 3. My university's strategic plan has 'student involvement in } \\
\text { governance as one of its priority action areas }\end{array}$ & 55 & 65.5 & 29 & 34.5 \\
\hline $\begin{array}{l}\text { 4. My university communicates the importance of student } \\
\text { involvement in governance to all members of the university } \\
\text { community }\end{array}$ & 67 & 79.7 & 17 & 20.3 \\
\hline $\begin{array}{l}\text { 5. My university has put in place mechanisms for the implementation } \\
\text { and enforcement of policies on student involvement in governance }\end{array}$ & 72 & 85,7 & 12 & 14,3 \\
\hline $\begin{array}{l}\text { 6. My university provides opportunities for public debate /discussion } \\
\text { of matters affecting student involvement in governance }\end{array}$ & 61 & 72.6 & 23 & 27.4 \\
\hline $\begin{array}{l}\text { 7. My university makes necessary amendments and revisions of } \\
\text { policies on student involvement in governance }\end{array}$ & 76 & 90.5 & 8 & 9.5 \\
\hline $\begin{array}{l}\text { 8. In my university student involvement in the various governance } \\
\text { structures and in decision making is a matter of policy }\end{array}$ & 78 & 92.9 & 6 & 7.1 \\
\hline $\begin{array}{l}\text { 9. My university's policy on student involvement in governance has a } \\
\text { constitutional and legal basis. }\end{array}$ & 81 & 96.4 & 3 & 3.6 \\
\hline
\end{tabular}

Key A=Agree $\mathrm{D}=$ Disagree

The results for the mainstreaming of students' participation in governance in institutional practices presented a positive picture, with more than 50 per cent of the students who took part in the study agreeing with any of the statements used to measure the variable. To illustrate, 73.8 per cent confirmed that university has a published policy on student involvement in governance. 60.7 per cent supported the view that statutes 
governing the university makes reference to student involvement in the governance process'.65.5 per cent agreed that university's strategic plan has 'student involvement in governance as one of its priority action areas and 79.7 per cent agreed that university communicates the importance of student involvement in governance to all members of the university community among others. These patterns were consistent with the views of student KIs and FGDs and the top university administrators who indicated that most students were aware of the existence of specific institutional practices that promotes the inclusion of students in governance processes of the University. One of the University manager said;

"There is university baraza a meeting of all students to discuss various matters as stipulated in the student constitution and university charter"

The results could also be considered to be the affirmation of the position taken by Zuo and Ratsoy (1999) that student representation on departmental committees appears to be the most strategic and potentially useful participative mechanism, because it aids problem solving at a local level, on issues that have an immediate impact on students, while offering the greatest potential for building a sense of community and social capital between staff and students. That students should be involved in governance is not a moot issue. After all students are full-time and possibly the most important stakeholders in the higher education community; meaning that they should participate in and wield considerable influence on institutional governance procedures, processes and activities (Persson 2003; Luescher 2011)

\section{Level of importance students in MWECAU attach to their participation in governance and decision making processes}

The second research question of this study was to assess the level of importance students in MWECAU attach to their involvement in governance structures and decision-making activities. This was captured through the analysis of student involvement in governance structures and participation of students in decision making process through questionnaires administered to 84 students, in-depth interviews with key informants (KIs) and focus group discussions (FGDs) with selected students. The survey results for levels of importance students in MWECAU attach to their participation in governance and decision making process are presented in Table 2

Table 2 Level of importance MWECAU students attach to their participation in governance and decision making processes

\begin{tabular}{|c|c|c|c|c|c|c|c|c|}
\hline \multirow[t]{2}{*}{$\begin{array}{l}\text { Item on Involvement in Governance } \\
\text { Structures }\end{array}$} & \multicolumn{2}{|c|}{$\begin{array}{l}\text { Not } \\
\text { involved at } \\
\text { all }\end{array}$} & \multicolumn{2}{|c|}{$\begin{array}{l}\text { Low } \\
\text { involvement }\end{array}$} & \multicolumn{2}{|c|}{$\begin{array}{l}\text { High } \\
\text { involvement }\end{array}$} & \multicolumn{2}{|c|}{$\begin{array}{l}\text { Very high } \\
\text { involvemen } \\
\text { t }\end{array}$} \\
\hline & $\mathrm{F}$ & $\%$ & $\mathrm{~F}$ & $\%$ & $F$ & $\%$ & $\mathrm{~F}$ & $\%$ \\
\hline 1. University Council/ Board of trustees & 34 & 40.5 & 35 & 41.7 & 10 & 11.9 & 6 & 7.1 \\
\hline 2. Management Council & 41 & 48.8 & 24 & 28.6 & 12 & 14.3 & 7 & 8.3 \\
\hline 3. Senate & 12 & 14.3 & 14 & 16.7 & 36 & 42.9 & 22 & 26.2 \\
\hline 4 All university wide committee & 5 & 6.0 & 11 & 13.1 & 41 & 48.8 & 27 & 32,1 \\
\hline 5. Deans' committee & 2 & 2.4 & 4 & 4.8 & 52 & 62.0 & 26 & 31.0 \\
\hline 6. All faculty-/ School-wide committees & 3 & 3.6 & 1 & 1.2 & 57 & 67.9 & 23 & 27.4 \\
\hline $\begin{array}{l}\text { 7. All departmental-/ programs-wide } \\
\text { committees }\end{array}$ & 2 & 2.4 & 1 & 1.2 & 46 & 54.8 & 35 & 41.7 \\
\hline \multicolumn{9}{|l|}{ Involvement in Decision Making Activities } \\
\hline $\begin{array}{l}\text { 1. Formulation of university vision and } \\
\text { missions }\end{array}$ & 8 & 9.5 & 11 & 13.1 & 34 & 40.5 & 31 & 37.0 \\
\hline 2. Strategic planning & 4 & 4.8 & 7 & 8.3 & 36 & 42.9 & 37 & 44.0 \\
\hline 3. Academic planning & 5 & 6.0 & 4 & 4.8 & 31 & 37.0 & 44 & 52.4 \\
\hline 4. Formulation of policies & 2 & 2.4 & 3 & 3.6 & 42 & 50 & 37 & 44.0 \\
\hline 5. Admission of new students & 3 & 3.6 & 8 & 9.5 & 37 & 44.0 & 36 & 42.9 \\
\hline 6. Orientation of new students & 1 & 1.2 & 1 & 1.2 & 12 & 14.3 & 70 & 83.3 \\
\hline 7. Curriculum design & 3 & 3.6 & 6 & 7.1 & 31 & 37.0 & 44 & 52.4 \\
\hline
\end{tabular}




\begin{tabular}{|l|l|l|l|l|l|l|l|l|}
\hline 8. Curriculum approvals & 2 & 2.4 & 1 & 1.2 & 39 & 46.4 & 42 & 50.0 \\
\hline 9. Program reviews & 1 & 1.2 & 2 & 2.4 & 37 & 44.0 & 44 & 52.4 \\
\hline 10. Curriculum development & 3 & 3.6 & 2 & 2.4 & 25 & 29.8 & 54 & 64.3 \\
\hline 11. Quality assurance & 1 & 1.2 & 2 & 2.4 & 32 & 38.1 & 49 & 58.3 \\
\hline 12. Student assessment & 0 & 0.0 & 0 & 0.0 & 45 & 53.8 & 39 & 46.4 \\
\hline 13. Student evaluation & 0 & 0.0 & 0 & 0.0 & 48 & 57.1 & 36 & 42.9 \\
\hline 14. Grading policy & 12 & 14.3 & 15 & 17.9 & 33 & 39.3 & 24 & 28.6 \\
\hline 15. Recruitment of faculty and staff & 26 & 31.0 & 24 & 28.6 & 22 & 26.2 & 12 & 14.3 \\
\hline 16. Faculty appraisal and promotions & 22 & 26.2 & 32 & 38.1 & 12 & 14.3 & 18 & 21.4 \\
\hline 17. Graduation planning & 3 & 3.6 & 4 & 4.8 & 33 & 39.3 & 44 & 52.4 \\
\hline 18. Disciplinary matters & 0 & 0.0 & 0 & 0.0 & 52 & 62.0 & 32 & 38.1 \\
\hline $\begin{array}{l}\text { 19. Support services committees (e.g. } \\
\text { library, ICT) }\end{array}$ & 12 & 14.3 & 19 & 22.6 & 23 & 27.4 & 30 & 35.7 \\
\hline 20. Closure and opening of the university & 5 & 6.0 & 10 & 12.0 & 26 & 31.0 & 43 & 51.2 \\
\hline
\end{tabular}

Data in Table 2 indicates the results of the responses from the participants who took part in the study showed that students attached high importance to their inclusion in various governance structures and in varied decision-making activities. With reference to governance structures, 69.1 per cent, 80.1 per cent 93.0 per cent, 85.3 per cent and 96.5 per cent respectively, considered student representation in the Senate, All university wide committee, Deans' committee, all faculty-/ School-wide committees and all departmental-/ programs-wide committees to be of high importance. Turning to lower level structures, 82.2 per cent and 77.4 per cent of participants, correspondingly, felt that involvement in University Council/ Board of trustees and Management Council was of low importance. Similar trends were observed for decision-making activities, with relatively low percentages of the respondents feeling that student involvement was not important at all. Out of the 20 areas of decision-making analyzed, students' involvement in 18 of them was considered to be of high importance by over 60 per cent of the respondents. Only in the two areas of recruitment of faculty and staff and faculty appraisal and promotions did the proportion of students who considered involvement in them to be of high importance stand at less than 50 per cent

These results were echoed by the KIs and the FGDs; in which most of the participants felt that, despite student representation at both the upper and lower levels of management, such representation was not effective. Concerning inclusivity, the study found that the university has not formulated formal structures for catering for divergent needs, including gender, disability, and non-traditional students such as postgraduate evening and weekend students, among other social categories. The results of this study showed that students considered it important to be involved in the various governance structures in their university. However, the greater premium appears to have been attached to involvement in committees at the various levels (Deans, university-wide, school-wide/ faculty-wide and departmental-wide/ programm-wide) relative to top-level structures, that is, University Council/ Board of Trustees, Management Councils and Senate. This could be interpreted to suggest that it is in such structures (committees) that students felt they made real impact as compared to high-level governance structures. This is consistent with the finding from in-depth interviews with key informants and focus group discussants that, especially on aspects regarding to students' representatives in governance and decision-making processes. It can also be argued that students attached greater premium to committees because it is at this level that important academic decisions that affect them directly are made. The results could also be considered to be the affirmation of the position taken by Zuo and Ratsoy (1999) that student representation on departmental committees appears to be the most strategic and potentially useful participative mechanism, because it aids problem solving at a local level, on issues that have an immediate impact on students, while offering the greatest potential for building a sense of community and social capital between staff and students

Extent, adequacy and level of satisfaction with student participation in governance and decision making processes in MWECAU

The respondents were also asked to rate the adequacy of students' involvement in the governance and decision-making processes utilizing a number of seven select indicators, that is: attendance in meetings, 
input/ contributions during meetings, representation of student issues, voting power, ability to influence decision-making, capacity to contribute solutions to problems faced by students, and feedback to students. As evident from Table 3

Table 3.Extent, adequacy and level of satisfaction with student participation in governance and decision making processes in MWECAU

\begin{tabular}{|l|l|l|l|l|}
\hline Statement & \multicolumn{2}{l|}{} & \multicolumn{2}{|l|}{} \\
& \multicolumn{2}{|l|}{ Inadequate } & \multicolumn{2}{|l|}{ Adequate } \\
\hline & $\mathrm{F}$ & $\%$ & $\mathrm{~F}$ & $\%$ \\
\hline 1. Attendance in meetings & 46 & 54.8 & 38 & 45.2 \\
\hline 2. Contributions during meetings & 49 & 58.3 & 35 & 41.7 \\
\hline 3. Representation of student issues & 32 & 38.1 & 52 & 62.0 \\
\hline 4. Voting power & 17 & 20.2 & 67 & 79.8 \\
\hline 5. Ability to influence decision making & 33 & 39.3 & 51 & 60.7 \\
\hline 6. Capacity to contribute solutions to problems faced by students & 10 & 12.0 & 74 & 88.0 \\
\hline 7. Feedback to students & 28 & 33.3 & 56 & 66.7 \\
\hline
\end{tabular}

The bulk of those who participated in the study rated students' representation of a number issues as adequate. With 62.0 per cent, 79.8 per cent, 60.7 per cent, 88.0 per cent and 66.7 per cent of respondents considered representation of student issues, , voting power, ability to influence decision making, capacity to contribute solutions to problems faced by students and feedback to students, respectively, to be adequate. Similarly, 54.8 per cent and 58.3 per cent of the participants concurred that attendance in meeting and contribution during meetings in that order, were inadequate

The inadequacy of students' involvement in governance and decision-making documented above was supported by qualitative data gathered for the study. Based on FGDs held with students, despite student representation at both the upper the lower levels of management, the focus group discussants felt that such representation was not effective. This was evident from the fact that 'issues took too long to be addressed, thereby discouraging students from airing their grievances. At the same time, attendance of meetings (e.g. departmental meetings) and consultative fora among student representatives was very poor, in some cases totally lacking. According to these informants, student leaders were mainly preoccupied with gratifying their personal and management's needs as opposed to being effective representatives of the student body.

\section{Challenges facing effective student participation in University governance, from the perspective of different stakeholders}

The final research question of this study was to identify the challenges to effective students' participation in University governance from the perspective of different stakeholders. The study showed that these were many and varied. among the leading challenges to effective students' participation that were identified by various stakeholder, the following ranked among the top five: 'Mistrust of student leaders among students leading to apathy' (84.8 per cent), 'lack of adequate recognition of students' role in university governance' (79.7 per cent), 'limited power and authority among student leaders' (68.7 per cent), 'fear of victimization by management among student leaders' (64.0 per cent) and 'lack of transparency and a consultative democratic process in university governance' ( 60.8 per cent). These were followed by challenges such as 'compromising of student's leaders by management' ( 56.7 per cent), 'lack of financial, physical and other supportive resources' (54.2 per cent), 'inadequate grievance and appeal structures' (53.1 per cent), 'management's tendency to impose decisions while ignoring students' inputs' (52.9 per cent) and 'lack of leadership capacity among students' (52.0 per cent). Other challenges to effective students' participation in university governance that were listed by at least 25.0 per cent of the participants were as follows: 'intimidation of student leaders by management' ( 45.4 per cent), 'management's lack of awareness of and/or insensitivity to students' needs' (40.7 per cent), 'poor communication between students' leaders and the general student body' (39.8 per cent), 'inadequate constitutional/legal basis to facilitate student participation in governance' (36.7 per cent), 'representation of individual rather than the group's interests by student 
leadership' (30.6 per cent), 'poor implementation of students' involvement policies and strategies' (29.8 per cent) and 'external interference especially by politicians and political parties' (27.9 per cent).

The qualitative data gathered from key informant interviews and focus group discussions supported the trends identified from the quantitative data. However, the KIs and the FGDs also identified other challenges undermining students' involvement in governance and decision-making processes. Ranking highly in this regard was apathy among students, as manifested through poor attendance of meetings. Indifference to governance process makes it difficult for student leaders to gather issues from different students and give feedback to the students, among others. The KIs and FGDs also singled out the one-year term students in elective offices served as another stumbling block to effective representation. According to them, 'one year is too short to make a difference'. Further, the KIs and FGDs identified the feeling among students that their opinions are not consequential as an additional impediment to student involvement in governance. Lack of interest in leadership roles among students in general and commitment to leadership among students leaders, balancing between academic work and leadership roles: student leaders often find it hard to attain such a balance., Lack of true democracy: despite the mainstreaming of students' involvement in governance in important university policy documents, students enjoy dwindling freedom to assemble and to voice their concerns.

\section{Conclusions of the study}

Mwenge Catholic University recognize, both in principle and practice, the importance of students' participation in governance processes. In this regard, policies, structures and support systems exist for the enhancement of students' participation in governance. However, a substantive number of student seems to be ignorant of opportunities available for student's participation in governance.

The nature and level of participation of students in the governance processes in Mwenge Catholic University has been well articulated by management and students attach high importance in their inclusion in various governance structures and in varied decision-making activities of the University. However, the greater premium appears to have been attached to participation in committees at the various levels (Deans, university-wide, directorate-wide/ faculty-wide and departmental-wide/ programm-wide) relative to toplevel structures, that is, University Council/ Board of Trustees, Management Councils and Senate.

Students' participation in university governance and in the making of key decisions that affect their academic and social welfare mainly occurs through students' self-governance councils as well as through students' participation in different committees (e.g. university-wide, school/ faculty and programme/departmental committees. However, there are other avenues such as clubs, associations and societies that may also present them with opportunities to influence the governance process.

Students value their overall participation in governance, including involvement in the various structures of governance and in the making of specific decisions that affect their academic and social welfare. In this regard, students have a good understanding of the positive and negative consequences of their integration into the governance process through their leadership/ elected representatives. They are also aware of the major challenges standing in the way to effective students' participation in the governance of universities.

There exists general mistrust of management and student leaders by the general student body. The mistrust emanates from the belief among the larger student community that leaders are mainly serving their own interests as opposed to the interests of their constituents. This tends to undermine the confidence students have in their leaders; it also casts doubts about the credibility and effectiveness of students' participation in governance processes.

\section{Recommendations of the study}

There is need for a paradigm shift within the University systems regarding the handling of students' participation in the governance process. In particular, well calculated and deliberate steps should be adopted to end the culture of tokenism and political correctness that currently pervade universities. For this to be judged to have taken root, management should elevate students, through their representatives, to the status of equal partners in the decision making processes. Only in this way will universities stem the apathy, lack of 
interest and the all too visible malaise characterizing both members of the student leadership and the larger student body in universities today with respect to participation in governance.

The university should formulate specific strategies for the nurturing and entrenching of a democratic and participative culture among students as well as among all cadre of management staff. This should entail the development of well-structured courses focusing on the development of leadership skills among students to complement the current practices of teaching leadership skills to student leaders through induction retreats and experiences through extra-curricular involvements. These should form part of the common courses and the general education courses offered by the university. Such courses should be compulsory for all students, regardless of their majors and programmes of study. The courses should teach students leadership skills; enlighten them about the importance of leadership attributes such as transparency, accountability, integrity, participation and teamwork, among others; whilst enhancing the students' understanding regarding their leadership identity, ability, and willingness to lead. This will, certainly improve both student participation in the governance processes of universities and the quality of the leadership offered by those bequeathed the mantle to represent the student body in varied capacities of leadership. Further importance of the courses lies in the fact that higher education is expected to educate individuals so they can become leaders in their chosen profession and in society. The leadership courses should, therefore, supplement rather than replace the leadership retreats that the universities conduct for newly-elected members of students' self-governance bodies, which in the eyes of many students have been turned into a form of reward for accepting to be a student leader as opposed to being opportunities for sharpening leadership skills

There is a need to review university policies on this subject matter to ensure that they truly actualize and nurture student participation in various levels of decision-making. This may be done in such a way that students are guaranteed that their voices count with respect to the making of major decisions affecting the running and operations of universities, as opposed to being participant observers as is currently the case in some university decision making process.

To change the negative attitude students have toward participation in university governance, universities should institutionalize teaching faculty, by way of encouraging faculty to discuss governance imperatives, including the advantages of effective students' representation, during their interactions with students in class. Similarly, the universities should impress on faculty who patron clubs and societies to use the clubs as avenues for spreading the governance gospel to students. The mentoring of student leadership should also be encouraged at the lower levels of management especially at the departmental and faculty/ directorate levels. In this regard, deans, heads of department, directors and chairs of lower-level committees should be encouraged to accord student representation greater voices in decision-making and incorporate some student leaders in their committees.

Where it is absolutely necessary for universities to make decisions without involving students or their representatives, this should be done guided by adequate scientific evidence or data collected from students focusing on their needs, desires, likes and dislikes. Only in this way will the situation in question be addressed effectively, and will the propensity for violent conflict between management and students be averted

University management speeds up the widening of the representation and the active participation of students (and staff) in governing bodies, and strengthens student (and staff) associations if it wishes to strengthen democratization of university governance. This will in turn increase their propensity to identify with outcomes of the governance processes in these institutions and reduce the incidences of student and/or staff conflict with management.

\section{References}

[1] Bailey, T., Cloete, N., and Pillay, P., 2013, Universities and Economic Development in Africa Case Study: Kenya and University of Nairobi, Wynberg: The Centre for Higher Education Transformation (CHET).

[2] Baker, J., 1997, What is Participatory Democracy? London: Community Workers Cooperative

[3] Bloom, D., Canning, D. and Chan, K., 2006, Higher Education and Economic Development in Africa,Washington DC: The World Bank 
[4] Bollen, K., 1990, 'Political Democracy: Conceptual and Measurement Traps', Studies in Comparative International Development, vol. 25, pp. 7-24.

[5] Bollen, K., 1993, 'Liberal Democracy: Validity and Method Factors in Cross- National Measures', American Journal of Political Science, Vol. 37: 1207-1230

[6] Brookes, S., 2006, 'Out with the Old, In with the New: Why Excellent Public Leadership Makes a Difference to Partnership Working', The British Journal of Leadership in Public Services, Vol. 2 (1), pp. 52-64.

[7] Castells, M., 1991, The University System: Engine of Development in the New World Economy, Washington DC: The World Bank.

[8] Cloete, N., Bailey, T., Pillay, P. Bunting, I. and Maassen, P., 2011, Universities and Economic Development in Africa, Wynberg: The Centre for Higher Education Transformation (CHET).

[9] Craig, J., 2005, Taking the Wide View: the New Leadership of Extended Schools, London: Demos.

[10] Dahl, R.A., 2006, Preface to Democratic Theory, Chicago: The University of Chicago Press

[11] Damtew, T. and Altbach, P.G., 2004, 'African Higher Education: Challenges for the 21st Century', Higher Education, vol 47, pp. 21-50.

[12] Effah, P., 2003, 'Ghana', in D. Teferra, and P.G. Altbach, eds, African Higher Education: An International Reference Handbook, Bloomington: Indiana University Press, pp. 563-573.

[13] Fung, A., 2007, 'Democratic Theory and Political Science: A Pragmatic Method of Constructive Engagement', American Political Science Review, Vol. 101 (3): 443-458.

[14] Gudo, C. O., Olel, M. A. and Oanda, I. O., 2011, 'University Expansion in Kenya and Issues of Quality Education: Challenges and Opportunities', International Journal of Business and Social Science, Vol. 2, No. 20, pp. 203-214.

[15] Jick, T. D., 1979, 'Mixing Qualitative and Quantitative Methods: Triangulation in Action', Administrative Science Quarterly, vol. 24, pp. 602-611.

[16] Jowi, J., 2003, 'Governing Higher Education in the Stakeholder Society: Rethinking the Role of the State in Kenya's Higher Education', paper presented at the CHEPS Summer School, June 29 - July 4, 2003, University of Maribor, Slovenia.

[17] Kauffeldt, J. K., 2009, 'The Commission for Higher Education in Kenya: A Case Study Regarding The Establishment, Role and Operations of an Intermediary Body in the Higher Education System of a Developing Nation', an unpublished Thesis submitted in conformity with the requirements for the Degree Doctor of Education, Ontario Institute for Studies in Education (Theory and Policy Studies), University of Toronto, Canada

[18] Kamara, A. and Nyende, L., 2007, 'Growing a Knowledge-Based Economy: Public Expenditure on Education in Africa', Economic Research Working Paper, No. 88. Tunisia: African Development Bank

[19] Kaburu, J. and Embeywa, E. H., 2014, 'An Evaluation of Quality of University Education in Kenya during this Massification Era', Mediterranean Journal of Social Sciences, Vol. 5 No 5, pp. 345-349.

[20] Kelly, M. J., 2001, Challenging the Challenger: Understanding and Expanding the Response of Universities in Africa to HIV/AIDS, Lusaka, Zambia: University of Zambia.

[21] Kinuthia, W., 2009, 'Educational Development in Kenya and the Role of Information and Communication Technology', International Journal of Education and Development Using ICT, Vol. 5, No. 2. (http://ijedict.dec.uwi.edu/viewarticle.php?id=740\&layout=html). January 28.2018

[22] Klemenčič, M., 2014, 'Student Power in a Global Perspective and Contemporary Trends in Student Organizing', Studies in Higher Education, Vol. 39, Issue. No 3, pp. 396-411.

[23] Lownsborough, H. and O'Leary, D., 2005, The Leadership Imperative: Reforming Children's Services from the Ground Up, London: Demos.

[24] Luescher-Mamashela, T. M., Kiiru, S., Mattes, R., Mwollo-Ntallima, A. M. Ng'ethe, N.and Romo, M., 2011, The University in Africa and Democratic Citizenship: Hothouse or Training Ground? Report on Student Surveys conducted at the University of Nairobi, Kenya, the University of Cape Town, South Africa, and the University ofDar es Salaam, Tanzania, Wynberg (South Africa): Centre for Higher education Transformation (CHET).

[25] Mosha, H. J., 1986, 'The Role of African Universities in National Developments: A Critical Analysis', Higher Education.15 (1), pp. 113-134. 
[26] Musisi, N. B. and Muwanga, N., 2003, Makerere University in Transition, 1993-2000: Opportunities and Challenges, Oxford: James Currey; Kampala: Fountain Publishers.

[27] Martin, E., Trigwell, K., Prosser, M. and Ramsden, P., 2003, 'Variation in the Experience of Leadership of Teaching in Higher Education', Studies in Higher Education, 28 (3), pp. 247-259.

[28] Mwiria, K., 1992, "University Governance: Problems and Perspectives in Anglophone Africa". AFTED Technical Note, No. 3, Washington, D.C.: The World Bank.

[29] Ndegwa, S., 2008, Kenya: Private University Growth of Mixed Blessing, (http:// www. Universityworldnews.com/article.php2.story.). February 12, 2018.

[30] Ngome, C., 2003, 'Kenya', in D. Teferra, and P.G. Altbach (eds.) African Higher Education: An International Reference Handbook. Bloomington: Indiana University Press, pp. 359 - 371

[31] Nyangau, J. Z., 2014, 'Higher Education as an Instrument of Economic Growth in Kenya', FIRE: Forum for International Research in Education, 1(1). (http://preserve.lehigh.edu/ fire/vol1/iss1/3). March 2, 2018.

[32] Obondo, A.T., 2000, 'Politics of Participatory Decision-Making: The Case of Kenyatta University and the University of Nairobi', French Institute for Research in Africa "Les Cahiers, Review no 19, November-December.

[33] Okioga, C. K., Onsongo, E. N., and Nyaboga, Y.B., 2014, 'Quality Issues in the Expansion of University Education in Kenya, the Human Resource Challenges and Opportunities', Chinese Business Review, Vol. 11, No. 6, pp. 596-605.

[34] Osseo-Asare, A. E., Longbottom, D. and Murphy, W. D., 2005, 'Leadership Best Practices for Sustaining Quality in UK Higher Education from the Perspective of the EFQM Excellence Model', Quality Assurance in Education, 12 (2), pp. 148-170.

[35] Persson, A., 2003, Student Participation in Governance of Higher Education in Europe, Council of Europe Survey.

[36] Ramsden, P., 1998, Learning to Lead in Higher Education, London: Routledge.

[37] Reisberg, L., 2010, Challenges for African University Leadership, (http://www.insidehighered. com/blogs/the_world_view/challenges_for_african_university leadership). January 172018.

[38] Saint, W., 2004, 'Comments on "Challenges Facing African Universities"', African Studies Review, 47 (1), pp. $61-65$.

[39] Sawyerr, A. 2004. "Challenges Facing African Universities: Selected Issues." African Studies Review, 47 (1), pp. 1 - 59

[40] Sethi, M., 2000, 'Return and reintegration of African Nationals', in Tapsoba, S., Kassoum S., Houenou, P. V., Oni, B., Sethi, M.and Ngu, J., eds, Brain Drain and Capacity Building in Africa, Dakar, Senegal: ECA/IRDC/IOM, pp. 38-48.

[41] Thierborn, G., 1977, 'The Rule of Capital and the Rise of Democracy', New Left Review, 103, pp. 3-41.

[42] Thurmond, V. A., 2001, 'The Point of Triangulation', Journal of Nursing Scholarship, 33 (3),pp. 253-258. United Republic of Tanzania, The Universities Act 2005. Government printers.

[43] Wainwright, H., 2005, Why Participatory Democracy Matters - And Movements Matter to Participatory Democracy, (https://www.tni.org/es/node/14262). February 24, 2018.

[44] Wondimu, H., 2003, 'Ethiopia', in Teferra, D. and Altbach, P.G., eds, African Higher Education: An International Reference Handbook, Bloomington: Indiana University Press, pp. 316 - 325.

[45] World Bank, 2009, Accelerating Catch-up: Tertiary education for growth in sub-Saharan Africa, Washington DC: The World Bank.

[46] Zuo, B. and Ratsoy, E.W., 1999, 'Student Participation in University Governance', Canadian Journal of Higher Education, 29, pp. 1-26. 